\title{
METODA UJI MODEL SEKSIONAL DEK SEBAGAI DASAR ANALISIS AEROELASTIK JEMBATAN BENTANG PANJANG
}

\section{TEST METHOD OF SECTIONAL MODEL DECK AS A BASIC ANALYSIS FOR LONG SPAN BRIDGE AEROELASTICITY}

\author{
Fariduzzaman \\ LAGG-BPPT, PUSPIPTEK Serpong, \\ Tangerang Selatan-15314, telp. 021-7560902, fax. 021-7560901, \\ e-mail: fariduzzaman@bppt.go.id
}

\begin{abstract}
Abstrak
Analisis eksperimental (uji terowongan angin) untuk rancangan jembatan bentang panjang, kebanyakan dilakukan dengan uji model seksional dan model penuh. Keduanya memiliki kelebihan dan kelemahannya. Namun uji model seksional lebih populer untuk digunakan pada analisis aerodinamika jembatan bentang panjang, sekalipun kemudian dilakukan juga uji model penuh. Karena itu uji model seksional dapat dianggap sebagai dasar atau langkah pertama untuk analisis aeroelastik jembatan bentang panjang. Makalah ini akan menguraikan beberapa aspek penting dari uji model seksional termasuk kelebihannya. Suatu studi kasus juga akan diberikan, untuk memberikan gambaran yang komprehensif dari proses uji model seksional. Sebagai kesimpulan dapat disampaikan bahwa, uji model seksional sebenarnya dapat memberikan seluruh parameter dasar aeroelastik yang diperlukan oleh perancang jembatan.

Kata kunci : Rancangan jembatan bentang panjang, Dinamika struktur, Getaran, Aeroelastika, Aerodinamika, Uji terowongan angin
\end{abstract}

\begin{abstract}
Experimental analysis (wind tunnel test) of long span bridge designs mostly perform in sectional or full model test, both has its good and weak points. The sectional model test is more popular to apply in many long span bridges aerodynamic analysis, eventhough the full model test should also be tested later on. Therefore the sectional model test can be regarded as a basic or starting step to the analysis of a long span bridge aeroelasticity. The following paper will describe several important aspects of sectional model test and its benefit. A case study will also be included to give a comprehensive figure of a sectional model test processes. As conclusion, the sectional model test can provide the whole basic aeroelastics parameters which is required by the bridge designer.
\end{abstract}

Keywords, Long-span bridge design, Structural dynamics, Vibration, Aeroelastic, Aerodynamics, Wind tunnel testing

Diterima (received) : 18 April 2016, Direvisi (reviewed) : 10 Mei 2016, Disetujui (accepted) : 15 Juni 2015

\section{PENDAHULUAN}

Jembatan bentang panjang adalah jembatan yang menjadi fleksibel karena bentangannya yang panjang. Rasio panjang terhadap lebar dek (slenderness ratio) tinggi atau strukturnya biasanya menggunakan penyangga kabel. Karena itu struktur jembatan bentang panjang menjadi sensitif terhadap beban angin (aerodynamic loads) dibanding beban gempa (seismic loads)
$18,20)$

Dalam beberapa hal, struktur jembatan bentang panjang juga memiliki karakteristik yang sama dengan sayap pesawat terbang. Perbedaannya yang mendasar, struktur jembatan mirip batang berpenumpu 
sederhana (simply supported beam) sedangkan sayap pesawat terbang adalah cantilever beam.

Uji terowongan angin berperan besar dalam verifikasi rancangan jembatan bentang panjang. Tanpa melalui uji terowongan angin, pembangunan jembatan bentang panjang memiliki resiko kerusakan yang sederhana dan berulang sampai yang sekaligus fatal menghancurkan.

Pada keadaan tertentu yang disebut kecepatan angin kritis, struktur jembatan bentang panjang dapat mengalami keadaan tak-stabil aeroelastik, baik yang temporer mengganggu seperti resonansi dengan fluktuasi aliran udara (vortex), maupun yang fatal menghancurkan seperti flutter.

Penggunaan model dalam analisis eksperimental aeroelastik jembatan bentang panjang, mulai dikenal ketika terjadi kehancuran jembatan Tacoma Narrow 1940. Pada waktu itu Jembatan Tacoma Narrow dianalisis dengan model penuh (full model) maupun model seksional. Namun kemudian sectional-model menjadi lebih populer penggunaanya karena dapat memberikan pula parameter yang dihasilkan model penuh, disamping praktis, ekonomis dan dapat dibuat dengan skala lebih besar.

Pada uji model-penuh, model mereplika bentuk geometri dalam 3 dimensi, begitupula karakteristik dinamika struktur dan aliran anginnya dibuat dalam 3 dimensi. Sehingga dapat dikatakan bahwa model mereplika hampir semua elemen-struktur dari jembatan bentang panjang, termasuk aliran angin sekitarnya yang bergerak dalam 3 Derajat Kebebasan (DOF - degree of freedom).

Pada model seksional, bentuk geometri maupun dinamika strukturnya mereplika gerakan potongan dek bagian tengah bentangan jembatan secara 2 DOF, termasuk aliran anginnya yang dibatasi pada 2 dimensi. Sebagai ilustrasi ditunjukkan tipikal pemasangan model uji seksional di Gambar 1 dan model uji penuh di Gambar 2.

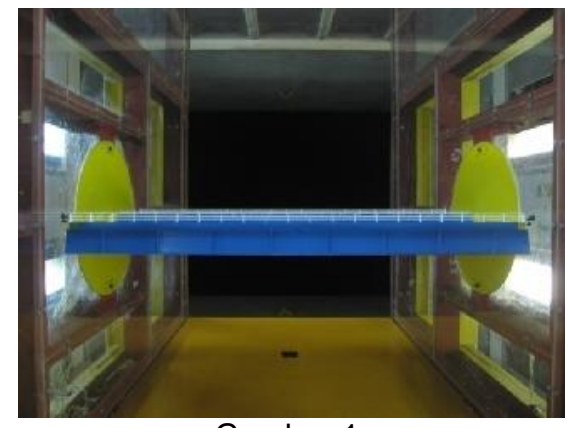

Gambar 1.

Tipikal Uji Model Seksional (Sectional Model)

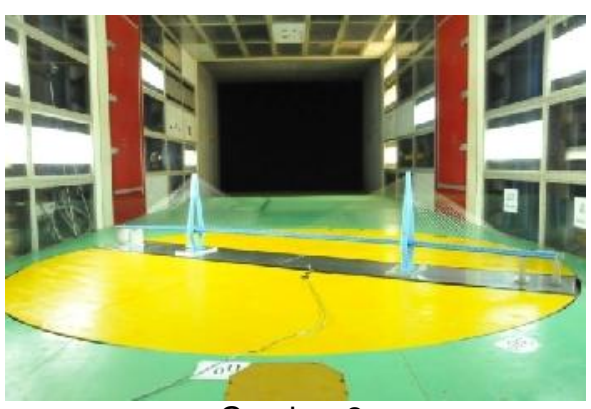

Gambar 2.

Tipikal Uji Model Penuh (Full Model)

Kini banyak ahli aerodinamika jembatan yang menyarankan bahwa apabila tujuan perencana hanya ingin mengetahui kecepatan kritis resonansi dan flutter maka uji model penuh dapat diabaikan. Uji model penuh sangat diperlukan apabila menghadapi kondisi berikut ini :

a) Adanya efek angin turbulen, sehingga terjadi gerakan acak pada dek jembatan dan mampu merubah karakteristik stabilitas jembatan ${ }^{111}$, dan;

b) Ditemukan fenomena khusus yang tidak lazim terjadi, misalnya defleksi lateral relatif besar pada jembatan dengan bentangan sangat panjang ${ }^{14)}$

Aspek lain yang terkadang dipertanyakan ketika menguji model jembatan seksional adalah jenis angin yang digunakan di terowongan angin. Karena angin alam adalah angin yang tak beraturan berbeda dengan angin di terowongan angin yang uniform dan tingkat turbulensinya yang rendah (smooth). Sekalipun pada dasarnya angin di dalam terowongan angin dapat diatur sebagai angin smooth (jarang terjadi di alam) atau angin turbulen (terjadi di alam).

Pengalaman menunjukkan bahwa dalam angin smooth, fenomena ketakstabilan aeroelastik lebih tegas terlihat. Sedangkan dalam aliran dengan tingkat turbulensi tinggi, fenomena ketakstabilan sering tertutup oleh osilasi random struktur yang naik secara gradual dengan naiknya kecepatan angin. Untuk itu, kini di LAGG (Laboratorium Aero-Gas dinamika dan Getaran), lebih banyak dilakukan uji model seksional dengan angin smooth. Gambar 3 menunjukkan Terowongan Angin ILST, dengan dimensi-nya ditunjukkan di Gambar 4. 


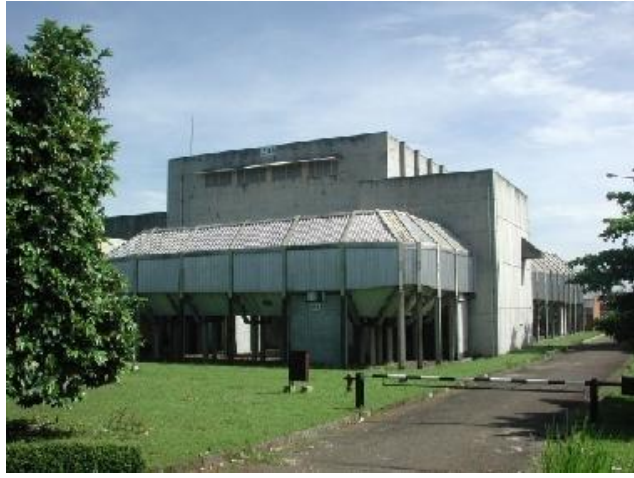

Gambar 3.

Tampak Depan Terowongan Angin ILST

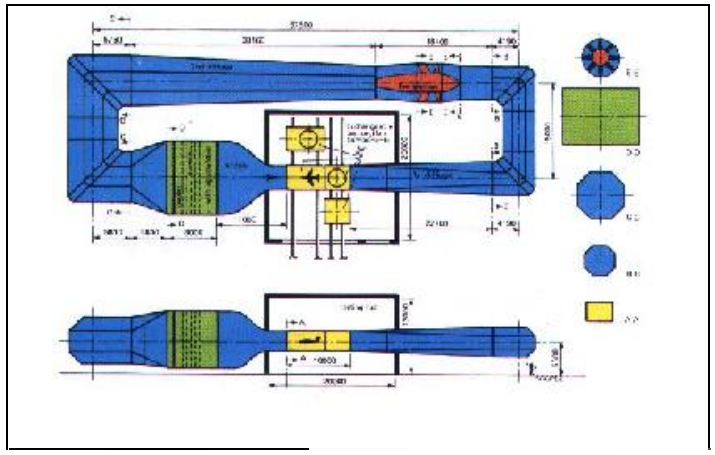

Gambar 4.

Dimensi dan Sketsa ILST

Dengan demikian, secara nasional Indonesia telah mampu menguji struktur jembatan bentang panjang, dengan tersedianya fasilitas terowongan angin ILST di PUSPIPTEK Serpong dan keahlian sumber daya manusia yang memadai ${ }^{11)}$.

\section{BAHAN DAN METODA \\ Studi Kasus}

Sebagai laboratorium aero-dinamika, lebih dari 10 jembatan bentang panjang Indonesia telah di uji dan di analisis di LAGG menggunakan terowongan angin ILST (Indonesian Low Speed Tunnel). LAGG kini menjadi satu-satunya operator terowongan angin di Indonesia yang dapat melakukan pengujian jembatan bentang panjang sesuai dengan Peraturan Menteri Pekerjaan Umum no. 448 / KPTS / M / 1995 tentang Klasifikasi dan Kualifikasi Laboratorium Pengujian Bidang Pekerjaan Umum yang minimal harus memiliki spesifikasi laboratorium uji angin sebagai berikut:

- Panjang : 60 m (1 sirkulasi pada sumbu tengah)

- Panjang : $10 \mathrm{~m}$ (dimensi maksimum)

- Tinggi diatas tanah $\min : 5.5 \mathrm{~m}$

- Kecepatan angin : $10-100 \mathrm{~m} / \mathrm{s}$

- Berat model : $25 \mathrm{~kg}$
Sebagai studi kasus, pengujian terowongan angin diambil dari suatu analisis desain jembatan bentang panjang yang akan dibangun di Propinsi Papua. Gambaran jembatan untuk studi kausu ditunjukkan pada Gambar 5. Jembatan adalah jenis Jembatan Gantung (Suspension Bridge) dengan model terowongan anginnya menggunakan skala perkecilan 1:40, atau $n=40$. Sehingga dapat dibuat perbandingan spesifikasi geometri antara model dan struktur sebenarnya seperti ditunjukkan di Tabel 1.

Tabel 1.

Perbandingan Dimensi (Skala model 1:40)

\begin{tabular}{lccccc}
\hline & $L_{\text {total }}$ & \multicolumn{1}{c}{$B_{\text {dek }}$} & $D_{\text {dek }}$ & $\begin{array}{c}H_{\text {dek- }} \\
\text { water }\end{array}$ \\
\hline $\begin{array}{l}\text { Prototype } \\
\text { Model- } \\
\text { Seksional }\end{array}$ & $960 \mathrm{~m}$ & $25.8 \mathrm{~m}$ & $3.5 \mathrm{~m}$ & $32 \mathrm{~m}$ \\
\hline
\end{tabular}

Pengujian dilakukan dalam seksi uji terowongan angin ILST, dengan terlebih dahulu memasang dummy wall sebagai penyangga model. Hal ini dilakukan agar ukuran model tidak terlalu besar (lebih ekonomis) tapi menjaga aliran angin supaya tetap 2 dimensi.

Model uji terowongan angin dibuat dengan tetap menjaga bentuk dan ukuran geometry yang selalu memenuhi skala perkecilan 1:40. Adapun bahan maupun sifat dinamika struktur model dirancang sedemikian rupa sehingga selalu memenuhi kaidah kesetaraan aeroelastik dan dinamika struktur.

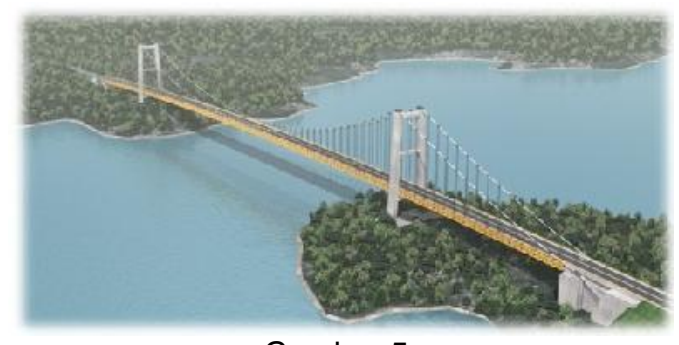

Gambar 5.

Gambaran Jembatan Untuk Studi Kasus

Dimensi keseluruhan jembatan ditunjukkan pada Gambar 6. Gambar 7 menunjukkan potongan melintang dek jembatan. 


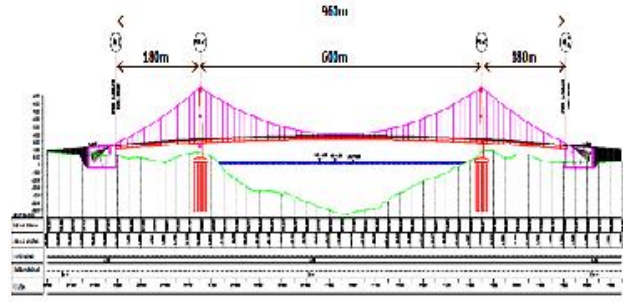

Gambar 6.

Dimensi Keseluruhan Jembatan untuk Studi Kasus

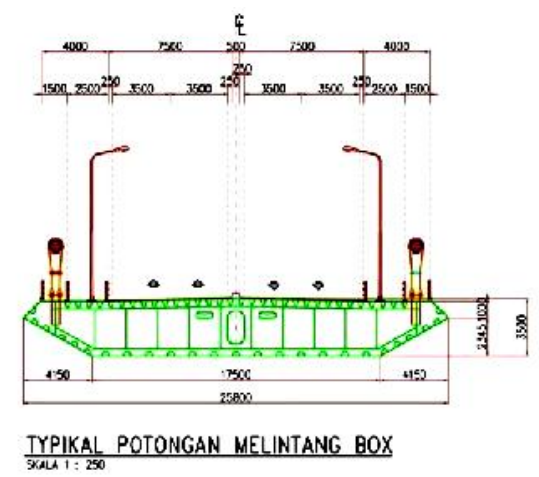

Gambar 7.

Bentuk dan Potongan Melintang Dek Dari Jembatan Untuk Studi Kasus

\section{Teori Aerodinamika Pada Jembatan}

Ketika aliran angin melalui suatu struktur fleksibel, maka timbullah fenomena aerodinamika mantab (steady) dan takmantab (unsteady). Aerodinamika mantab menimbulkan gaya dan momen aerodinamika mantab di struktur itu sendiri. Aerodinamika tak-mantab terjadi karena struktur yang dilaluinya fleksibel, sehingga terjadi interaksi dinamik antara aerodinamika dan dinamika struktur, yang dikenal dengan fenomena aeroelastik.

Gaya dan moment aerodinamika mantab dapat diperoleh secara eksperimental maupun komputasional. Namun hasil analisis CFD (Computational Fluid Dynamics) dalam beberapa hal, akurasi nilai kuantitatifnya masih meragukan, terutama untuk bentukbentuk non-streamline seperti struktur dek jembatan. Hasil CFD banyak berperan dalam memperoleh kesimpulan global atau trend data, serta analisis medan aliran.

Lain halnya dengan hasil analisis eksperimental, pada umumnya hasilnya akan akurat selama kualitas model yang dibuat memenuhi spesifikasi yang ditentukan, serta metoda pengukuran yang digunakan sesuai dengan standar uji aerodinamik.

Untuk mengukur gaya dan momen aerodinamika mantab pada model seksional, dilakukan dengan:
- Alat ukur gaya (timbangan / balance) yang dipasang pada as (shaft) model seksional dek ${ }^{\text {(8) }}$

- Alat ukur tekanan yang dipasang di seluruh lubang tekanan yang mengelilingi sisi permukaan irisan model

Pengukuran dengan timbangan sifatnya praktis dan langsung, artinya gaya $\mathrm{N}$ (norma), $\mathrm{T}$ (tangential) dan M (moment) dapat diketahui langsung dari alat ukur. Sedangkan pengukuran dari tekanan tidak praktis dan tidak langsung, artinya gaya N, T dan momen $\mathrm{M}$ baru dapat diketahui setelah melalui proses integrasi tekanan yang dinyatakan dalam bentuk koeffisien tekanan $(\mathrm{Cp})$. Distribusi pengukuran tekanan pada model ditunjukkan di Gambar 8. Gambar 9 menunjukkan notasi dan arah gaya dan momen pada model.

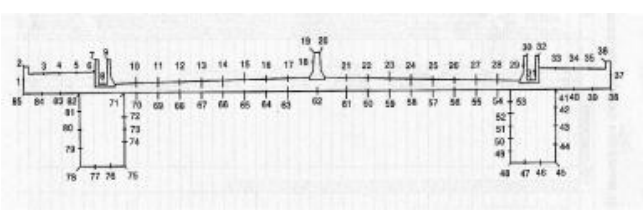

Gambar 8.

Tipikal Distribusi dan Urutan Nomor Lubang Tekanan

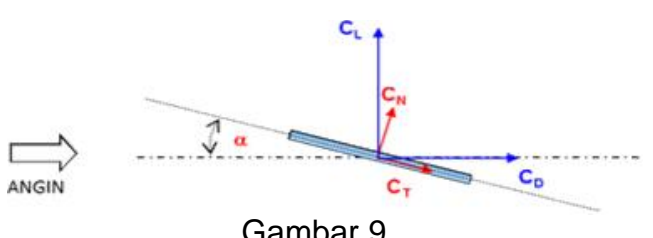

Notasi dan Arah Gaya - Momen di Model ${ }^{2)}$

Jika $p_{i}$ adalah tekanan di lubang $k e \mathrm{i}, \rho$ adalah kerapatan udara dan $U$ adalah kecepatan aliran angin. Maka koeffisien tekanan di definisikan sebagai berikut ${ }^{1)}$,

$C p_{i}=\frac{p_{i}}{q}$

dimana,

q adalah tekanan dinamik, yang di

definisikan,

$q=\frac{1}{2} p U^{2}$

Kemudian koeffisien gaya normal $\left(\mathrm{C}_{\mathrm{N}}\right)$, koeffisien gaya tangential $\left(\mathrm{C}_{\mathrm{T}}\right)$ dan koeffisien momen dapat ditentukan dari integrasi berikut 2),

$\mathrm{C}_{\mathrm{N}}=-\frac{1}{\mathrm{~b}} \oint \mathrm{Cpdx}$

$\mathrm{C}_{\mathrm{T}}=+\frac{1}{\mathrm{~b}} \oint \mathrm{Cpdy}$ 
$\mathrm{C}_{\mathrm{N}}=\frac{1}{\mathrm{~b}^{2}}[\oint \mathrm{Cp} \cdot \mathrm{x} \cdot \mathrm{dx}+\oint \mathrm{Cp} \cdot \mathrm{y} \cdot \mathrm{dy}]$

$\mathrm{C}_{\mathrm{L}}$ adalah transformasi $\mathrm{C}_{\mathrm{N}}$ terhadap sumbu angin melalui sudut $\alpha, C_{D}$ adalah transformasi $C_{T}$ terhadap sumbu angin melalui sudut $\alpha, C_{M}$ adalah sama untuk $\alpha=0$ dan $\alpha \neq 0$. Maka gaya angkat $L$, gaya hambat $\mathrm{D}$ dan momen puntir $\mathrm{M}$ dapat dihitung dari persamaan berikut ${ }^{3)}$,

$L=q \cdot B \cdot C_{L}$

$\mathrm{D}=\mathrm{q} \cdot \mathrm{B} \cdot \mathrm{C}_{\mathrm{D}}$

$M=q \cdot B^{2} \cdot C_{M}$

dimana,

$\mathrm{U}:$ kecepatan aliran angin $[\mathrm{m} / \mathrm{s}], \mathrm{B}$ : lebar dek jembatan $[\mathrm{m}]$.

\section{Teori Aeroelastik Pada Jembatan}

\section{Induksi Resonansi}

Osilasi atau getaran dapat muncul di struktur jembatan bentang panjang karena induksi resonansi, baik oleh angin seperti fluktuasi vortex atau oleh gerakan mekanik seperti kendaraan yang lewat atau faktor seismik. Fenomena ini disebut dengan Resonance Induced Vibration $(R I V)^{5}$.
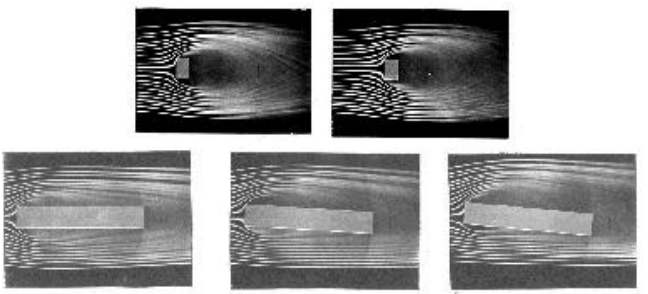

Gambar 10.

Tipikal Struktur Tidak Streamline dan Perubahan Sudut Serang ( $\square)$

Pelepasan aliran (separation) dari permukaan struktur akan diikuti dengan pembentukan vortex di wake (belakang benda) yang disebut pula vortex shedding atau Von Karman Vortex ${ }^{4}$.

- Jika struktur berbentuk silinder atau ellips, maka titik separasi akan bergeser posisinya sesuai dengan bilangan Reynolds $(R e)$ yang terjadi

- Jika struktur berbentuk tidak streamline (banyak tepi tajam) maka posisi titik separasi akan tetap posisinya, yakni di permukaan yang tajam tersebut. Dengan kata lain jika ini terjadi, maka efek bilangan Reyolds dapat di relaksasi.

Karena pembentukan vortex di wake menunjukkan suatu ulakan yang periodik seperti pada Gambar 10 dan 11, maka vortex ini menghasilkan pula suatu frekuensi fluktuasi yang disebut dengan frekuensi Strouhal $\left(f_{s}\right)^{6)}$.

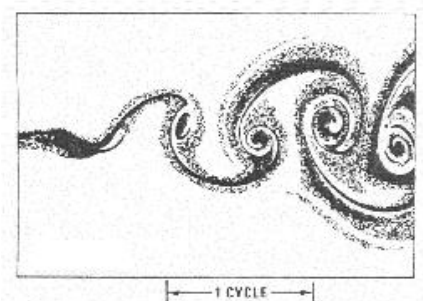

Gambar 11

Siklus Vortex

Frekuensi vortex (frekuensi Strouhal, $f_{s}$ ) yang dihasilkan akan dipengaruhi oleh kecepatan angin yang mengalir (U), karena itu Strouhal menemukan hubungan ini sebagai suatu bilangan konstan yang dikenal dengan Bilangan Strouhal (St). Apabila $d$ adalah ukuran dimensi rujukan dari struktur, maka hubungan tersebut adalah ${ }^{3)}$,

$\mathrm{St}=\frac{\mathrm{f}_{\mathrm{g}, \mathrm{d}}}{\mathrm{u}}$

Tampak bahwa $f_{s}$ berbanding lurus dengan U. Sehingga apabila dilakukan eksperimen dan osilasi struktur diukur dengan accelerometer, maka fenomena ini akan terlihat sebagai puncak-puncak kurva akselerasi yang frekuensinya bergeser dengan perubahan kecepatan angin. Sedangkan kemiringan kurva (slope) akan sama dengan ${ }^{6)}$.

$\operatorname{tg} \alpha=\frac{S t}{d}$

dimana, St dan d adalah konstan.

Dengan berubahnya $U$ frekuensi fluktuasi vortex akan bergeser pula. Jika suatu ketika pegeseran $f_{s}$ mendekati atau berimpit dengan salah satu frekuensi natural struktur $\left(f_{H}-\right.$ Heaving, $f_{T}-$ Torsion atau $f_{L}-$ Latera), maka fenomena resonansi akan terjadi. Secara simulasi CFD fenomena pembentukan vortex di tunjukkan di Gambar 12. Struktur akan berosilasi dengan amplitudo yang tiba-tiba naik dengan bertambahnya kecepatan angin, sampai pada satu kecepatan dimana amplitudo osilasi jadi maksimum pada kecepatan angin kritis. Kemudian jika kecepatan angin terus dinaikan, maka setelah kecepatan angin kritis ini, amplitudo osilasi akan turun kembali secara cepat. 


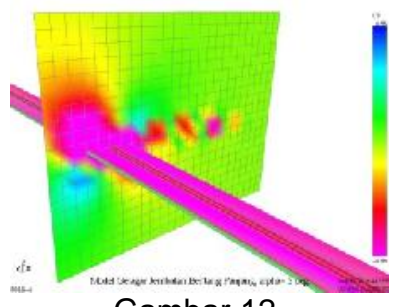

Gambar 12.

Tipikal Simulasi Pembentukan Vortex di Dek Jembatan

Gambar 13 menunjukkan pergeseran frekuensi osilasi dari frekuensi Strouhal $\left(f_{s}\right)$ dengan bertambahnya kecepatan angin. Maka ketika frekuensi Strouhal berimpit dengan frekuensi natural torsi untuk struktur $\left(f_{T}\right)$ terjadilah resonansi. Dari fenomena ini dapat dilihat bahwa induksi osilasi pada struktur dek jembatan terjadi karena fluktuasi vortex di wake, karena itulah fenomena ini disebut dengan Vortex Induced Vibration (VIV). Kecepatan angin kritis dimana VIV terjadi ditulis $U_{\text {VIV }}$. Selanjutnya apabila diamati secara cermat, kenaikan amplitudo frekuensi Strouhal (vortex shedding frequency) tidak hanya terjadi di satu kecepatan angin $U_{V I V}$ saja, tapi juga dalam satu jangkauan (range) kecepatan. Sebelumnya amplitudo mulai naik dari satu kecepatan angin rendah, kemudian bertambah tinggi dan puncak resonansi terjadi di $U_{\text {VIV. }}$ Apabila kecepatan angin semakin tinggi maka amplitudo kini turun dan berakhir di satu kecepatan angin.

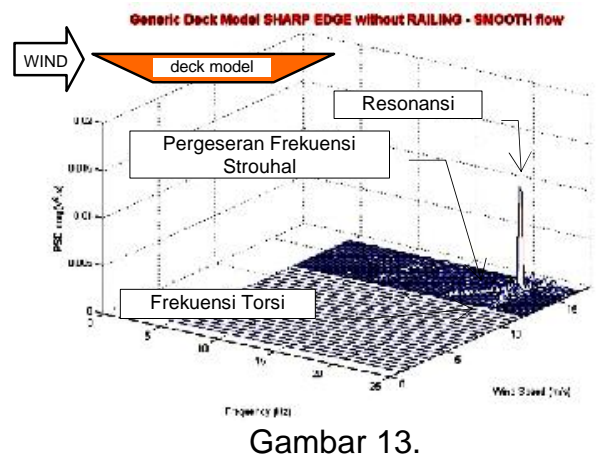

Pergeseran Frekuensi Strouhal dan Eksitasi Amplitudo Osilasi Oleh Resonansi

Fenomena bertahannya osilasi struktur pada satu frekuensi dengan kecepatan angin yang berubah, dikenal sebagai fenomena lock-in. Fenomena lock-in ini ditunjukkan di Gambar 14. Struktur melepaskan diri dari lock-in karena telah memiliki energi yang cukup. Diluar lock-in frekuensi osilasi akan bergeser dengan perubahan kecepatan angin (flow velocity).

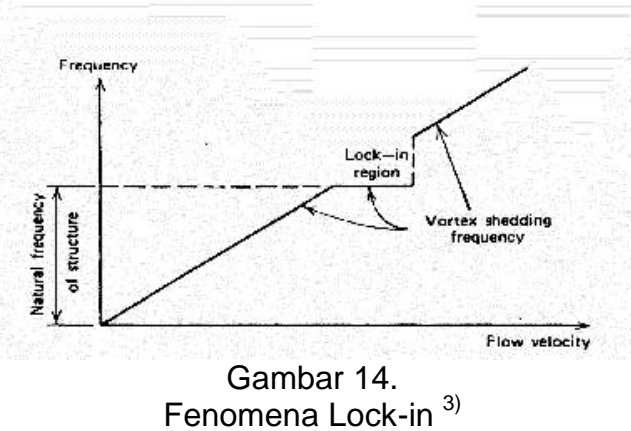

Fenomena menarik lainnya yang terjadi dari induksi resonansi adalah proses separasi / pemisahan aliran di permukaan dek, yakni terlepasnya aliran dari permukaan struktur, baik karena aliran permukaan yang terhalang (obstacle) seperti pagar atau karena permukaannya yang tidak streamline. Pemisahan aliran yang menimbulkan induksi resonansi karena aliran yang terhalang ditunjukkan pada Gambar 15.

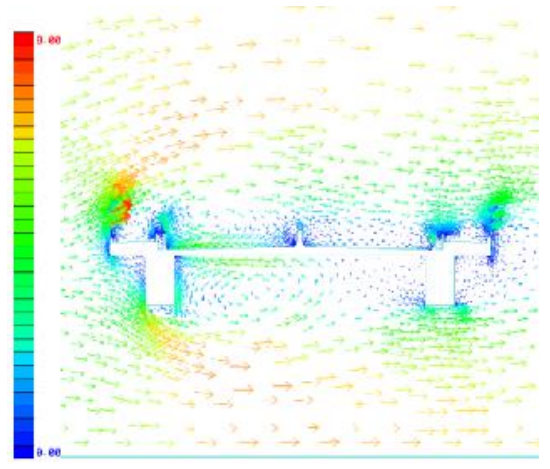

Gambar 15.

Separasi karena aliran terhalang: Pagar (railing), Pemisah Jalur (lane-separator) dan Gelagar (girder)

Karena distribusi separasi antara bagian atas dan bawah permukaan dek berbeda, maka distribusi tekanan udara pun akan berbeda ${ }^{15}$. Sehingga fenomena ini menginduksi getaran dek jembatan secara vertikal (heaving) dengan kecepatan angin yang bisa sangat rendah. Fenomena ini disebut dengan LSHR (Low-wind Speed Heaving Resonance) dan kecepatan angin kritis dimana LSHR terjadi dituliskan, U USHR. Kejadian LSHR pada dek jembatan ditunjukkan pada Gambar 16. 


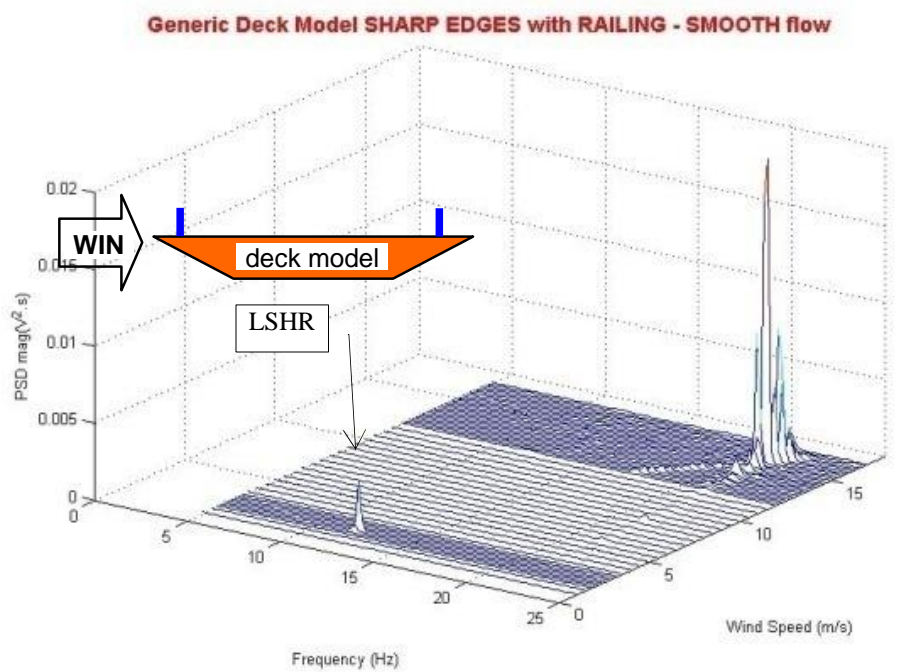

Gambar 16.

Resonansi LSHR

Fenomena resonansi pada struktur jembatan bentang panjang menimbulkan fenomena yang disebut dengan LCO (Limited Cycle Oscillation), yakni terjadinya osilasi pada komponen struktur jembatan dengan siklus terbatas dan tidak segera merusak.

Hampir sebagian besar jembatan fleksibel tidak dapat menghindari $L C O$, baik oleh: induksi vortex, LSHR maupun buffeting. Untuk mengatasi hal ini langkah pertama yang harus dilakukan oleh perencana adalah mencari profil penampang yang paling kecil memberikan efek $L C O$, apakah melalui cobacoba di terowongan angin maupun analisis komputasional (Computational Fluid Dynamics, CFD). Efek negatif $L C O$ baru timbul jika tidak diantisipasi sejak awal atau kurangnya perawatan jembatan selama operasionalnya. Oleh sebab itu fenomena aeroelastik akan terjadi pada jembatan bentang panjang seperti yang ditunjukkan pada Gambar 17. Untuk mempelajari fenomena aeroelastik ini, dek jembatan perlu diuji di terowongan angin dengan model fisika gerakan dek seperti ditunjukkan pada Gambar 18.

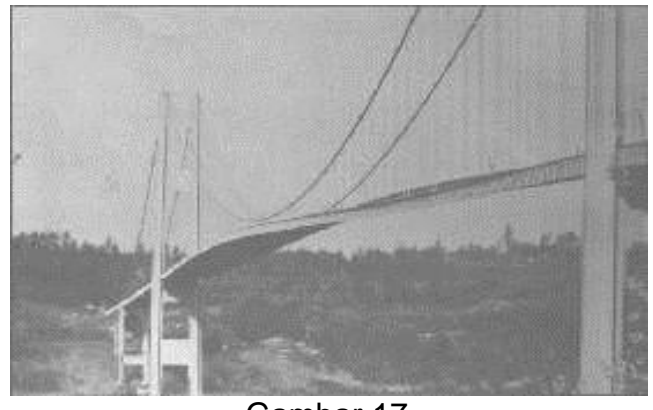

Gambar 17.

Fenomena Aeroelastik ${ }^{3)}$

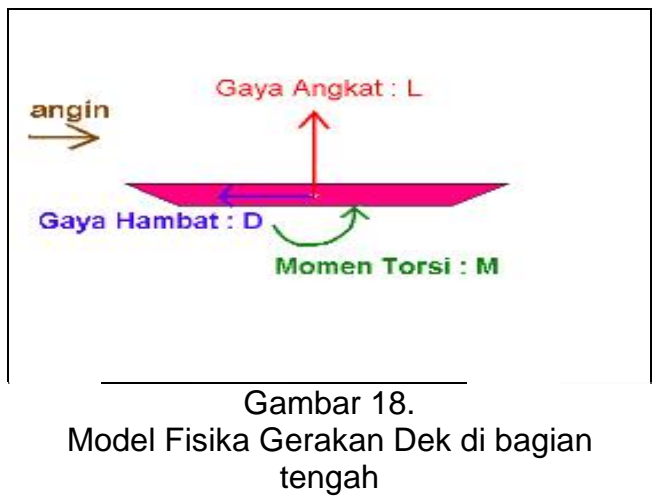

Hal-hal yang mungkin terjadi oleh $L C O$ adalah:

- Fatigue (kelelahan komponen struktur), sehingga dalam periode waktu tertentu setiap komponen struktur harus di periksa ketahanannya dan jika perlu diganti baru.

- Serviceability atau Comfort Level (Tingkat Kenyamanan). Batasan Comfort Level akan berbeda antar berbagai negara, tergantung kepada code yang ditetapkan oleh standar konstruksi negara tersebut.

- British design rules ${ }^{7}$, menetapkan batas akselerasi maksimum untuk comfort yakni jika kecepatan angin antara $0 \mathrm{~m} / \mathrm{s}-20 \mathrm{~m} / \mathrm{s}$ maka akselerasi puncak harus $<0,04 \mathrm{~g}$.

- Sedangkan ASCE (American Society of Civil Engineer) ${ }^{7)}$ menetapkan bahwa untuk,

- kecepatan angin < 13,5 m/s akselerasi puncak harus $<0.05 \mathrm{~g}$

- kecepatan angin antara 13,5 $\mathrm{m} / \mathrm{sec}-20 \mathrm{~m} / \mathrm{sec}$ akselerasi puncak harus $<0,1 \mathrm{~g}$ 
Flutter

Untuk model seksional, kecepatan kritis flutter $\left(\mathrm{U}_{\mathrm{f}}\right)$ dapat ditentukan dengan metoda Flutter Margin dari Zimmermann ${ }^{13)}$. Metoda ini diperoleh melalui perhitungan langsung dari data pengukuran frekuensi osilasi dan redaman masing-masing mode dari model selama mendapat aliran angin. Kecepatan kritis flutter diperoleh dari ekstrapolasi kurva Flutter Margin (Fm) ke sumbu horizontal (sumbu U, Kecepatan Angin).

$$
\begin{aligned}
& F m=\left[1-\left(\frac{\beta_{h}-\beta_{p}}{\beta_{h}+\beta_{p}}\right)^{2}\right]\left\{\left(\frac{\omega_{h}^{2}-\omega_{p}^{2}}{2}\right)^{2}+\right. \\
& \left.\left(\beta_{h}+\beta_{p}\right)^{2}\left[\left(\frac{\omega_{h}^{2}+\omega_{p}^{2}}{2}\right)+\left(\frac{\beta_{h}+\beta_{p}}{2}\right)^{2}\right]\right\}
\end{aligned}
$$

dimana, $\beta_{\mathrm{h}}$ - faktor redaman osilasi heaving, $\omega_{\mathrm{h}}$ - frekuensi osilasi heaving, $\beta_{\mathrm{p}}$ - faktor redaman osilasi pitching dan $\omega_{p}$ - frekuensi osilasi pitching.

\section{Parameter Kesetaraan}

Model seksional harus dibuat sedemikian rupa sehingga dapat mereplika bentuk geometry secara maksimal serta mensimulasikan gerakan potongan dek jembatan di bentang tengah. Pada bagian ini gerakan dek dapat di sederhanakan menjadi 2 DOF (Degree of Freedom): Vertical Bending (heaving) dan Torsion, atau dalam kasus khusus dapat terjadi gerakan lateral sehingga menjadi 3 DOF: Vertical Bending, Lateral Bending dan Torsion ${ }^{18)}$.

Dengan demikian pengujian model seksional dek jembatan harus menerapkan kaidah kesetaran (similarity rule) aeroelastik, yakni kaidah kesetaraan yang didasarkan pada aspek: Aerodinamika dan Dinamika Struktur ${ }^{8,21)}$.

Kesetaraan aerodinamika dinyatakan dengan replika bentuk yang semirip mungkin dengan rancangan dek sebenarnya dan dimensi model adalah dimensi perkecilan (scale down) dari ukuran dek sebenarnya. Skala perkecilan yang memadai untuk uji model seksional adalah antara 1:20 atau $\mathrm{n}=20$ sampai dengan $1: 60$ atau $\mathrm{n}=60$.

$d=\frac{D}{n}$

dimana

$\mathrm{d}=$ dimensi model, $\mathrm{D}=$ dimensi prototype
Sebagai konsekwensi kesetaraan geometri dan dimensi, maka kesetaraan berikut juga berlaku:

$\frac{z_{\text {akt }}}{z_{\text {ta }}}=\frac{b_{\text {prototype }}}{b_{\text {model }}}=\frac{B}{b}=n$

dimana,

$\mathrm{z}_{\mathrm{akt}}$ : ketinggian aktual di lingkungan alam sebenarnya (misalnya ketinggian dek terhadap permukaan air).

Kesetaraan dinamika struktur diwakili dari rasio frekuensi natural gerak vertical bending (heaving) dengan rotasi dek (torsion). Karena dari parameter frekuensi inilah karakteristik dinamika struktur telah dimiliki secara intrinsik ${ }^{9}$.

$\left[\frac{f_{b}}{f_{\theta}}\right]_{\text {model }}=\left[\frac{f_{b}}{f_{\theta}}\right]_{\text {protatype }}$

Hal lain yang penting untuk koreksi adalah faktor redaman, secara ideal rasio redaman di model harus setara dengan rasio redaman struktur jembatan sebenarnya. Namun pada saat jembatan dirancang, maka struktur sebenarnya belum ada. Sehingga parameter redaman hanya dapat diperoleh dari perhitungan software FEM (Finite Element Method) yang digunakan. Karena itulah faktor redaman ini akan bersifat seadanya dan jauh dari nilai sebenarnya.

Salah satu cara untuk mendapatkan kesetaraan redaman yang memadai adalah dengan menghilangkan segala kemungkinan friksi di model, sehingga redaman struktur $\zeta$ akan sangat kecil, biasanya antara 0,005 0,015 . Ini adalah nilai redaman jembatan prototype. Hal ini hanya bisa dilakukan dengan membuat uji model seperti yang ditunjukkan pada Gambar 19. Gambar 20 menunjukkan sketsa struktur dan konfigurasi model seksional.

$\zeta_{\text {model }}=\zeta_{\text {prototype }}$

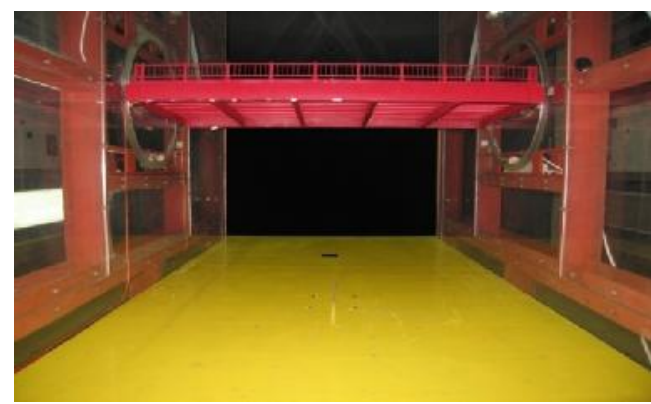

Gambar 19.

Tipikal Model Seksional di Terowongan Angin 


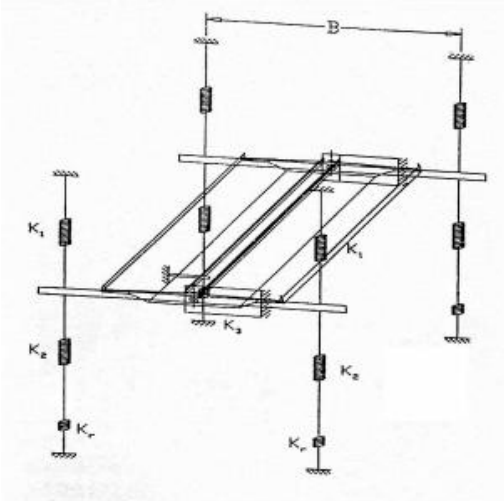

Gambar 20.

Sketsa Struktur dan Konfigurasi Model Seksional ${ }^{9,10,19)}$

Dalam pengujian model yang memiliki bentuk geometri non-streamline, umumnya pengaruh bilangan Reynolds $(R e)$ sulit untuk diperhitungkan, karena separasi aliran dapat terjadi secara permanen pada tepi yang tajam, pergeseran titik separasi akibat perubahan Re tidak terjadi. Dengan demikian kaidah similaritas $R e$ akan berbeda dengan struktur benda yang streamline. Antara jembatan aktual (prototype) dengan model akan terjadi perbedaan Re beberapa orde. Kasus seperti ini berlaku pada sebagian besar jembatan bentang panjang ${ }^{3,12)}$.

Sekalipun demikian beberapa hal berikut harus diperhatikan ${ }^{17)}$ :

a. Untuk elemen struktur yang sangat kecil (misalnya railing), Re dapat turun sampai $<100$, akibatnya gaya-hambat (drag) menjadi dominan karena efek viskositas ${ }^{6}$. Untuk itu, pemodelan elemen struktur demikian lebih baik menggunakan cara lain seperti,

- jumlahnya dibatasi

- diameter elemen tersebut diperbesar,

- digunakan model dengan skala yang cukup besar, $1: 100$ sampai $1: 300$

- menggunakan struktur lain tapi memiliki rasio kekosongan / porositas yang sama

b. Elemen struktur berbentuk silinder bulat (seperti kabel atau pagar) akan lebih sensitif terhadap perubahan $R e$, karenanya harus dicermati sejak dini.

c. Untuk benda bertepi tajam, pola reattachement aliran setelah separasi dan resirkulasi di wake, menurut rujukan kurang sensitif terhadap perbedaan Re. Aliran resirkulasi dan separasi ini sering dijadikan rujukan untuk mendapatkan akurasi simulasi jika kesetaraan Re tak terpenuhi. Selain itu efek $R e$ mungkin berkaitan pula dengan rasio blockage terowongan angin. Begitupula reattachment aliran akan sensitif terhadap roughness permukaan benda dan turbulensi dari angin datang ${ }^{2,3,4)}$.

d. Agar efek turbulensi sama pada Re yang berbeda, maka sangat penting untuk mensimulasikan spektrum kecepatan angin secara tepat.

e. Jika Re kecil maka simulasi turbulensi angin alam menjadi tidak akurat, karena rasio ukuran dari eddy akan sangat tergantung pada viskositas ${ }^{2)}$.

$\mathrm{Re}=\frac{\rho \mathrm{Ub}}{\mathrm{v}}$

dimana, $v$ : viskositas kinematik, (untuk sea-level $=1,789 \times 10^{-5} \mathrm{~kg} / \mathrm{m}$.det.)

Parameter kesetaraan lainnya yang penting untuk model seksional adalah Bilangan Strouhal (St), Persamaan (9). Bilangan ini sering digunakan untuk transformasi kecepatan di terowongan angin ke kecepatan jembatan sesungguhnya (prototype) ${ }^{10)}$. Dimana hasil uji terowongan angin akan digunakan untuk memperkirakan karakteristik jembatan sesungguhnya setelah melalui proses ekstrapolasi data eksperimen ke data aktual. Untuk uji jembatan ada 2 parameter penting yang harus diekstrapolasikan: displacement dan kecepatan angin.

- Displacement $\delta$ adalah para-meter geometri yang diekstra-polasi dengan perkalian terhadap skala model $\mathrm{n}^{3 \text { ) }}$.

$$
\delta_{\text {prootorpe }}=n . \delta_{\text {model }}
$$

- Kecepatan diekstrapolasi dengan kesetaraan bilangan Strouhal St, atau frekuensi-reduksi (reduced frequency) $\mathrm{k}$ 10),

$$
\begin{aligned}
& \mathrm{k}_{\text {prototype }}=\mathrm{k}_{\text {model }}
\end{aligned}
$$

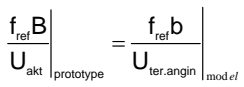

$$
\begin{aligned}
& U_{\text {akt }}=\frac{\mathrm{f}_{\text {refe }}, \mathrm{B}}{\mathrm{f}_{\text {ret, }, \mathrm{B}} \mathrm{b}} U_{\text {terangin }}
\end{aligned}
$$

\section{PEMBAHASAN DAN HASIL}

Tipikal jembatan bentang panjang yang dijadikan untuk studi kasus telah ditunjukkan di Gambar 5, 6 dan 7. Kemudian berdasarkan data geometri dan dimensi Tabel 1, maka dibuatlah model seksional dek seperti di tunjukkan di Gambar 21. 


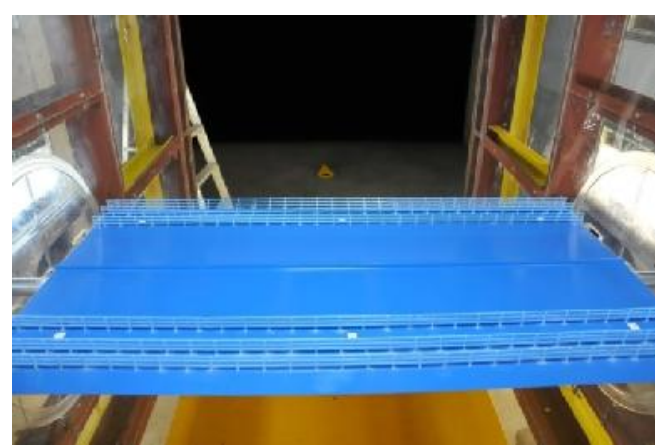

Gambar 21

Model Seksional Untuk Studi Kasus

\section{Uji Model Statik}

Uji model statik dilakukan untuk mendapatkan data gaya dan momen aerodinamika steady, yaitu $C_{L}, C_{D}$ dan $C_{M}$ sesuai dengan Persamaan (3) sampai dengan (8).

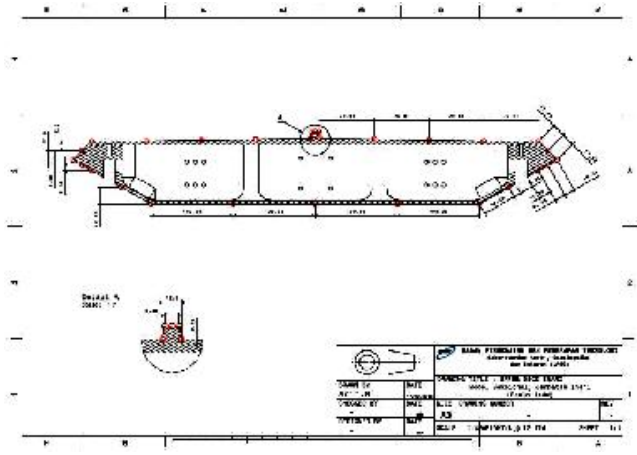

Gambar 22.

Pengaturan Distribusi Lubang Tekanan Model

Dek serta Desain Lubang Tekanan

Pengukuran tekanan untuk uji model statik pada studi kasus ini dilakukan dengan mengatur distribusi lubang tekanan seperti ditunjukkan di Gambar 22. Sedangkan hasilnya ditunjukkan di Gambar 23, 24 dan 25.

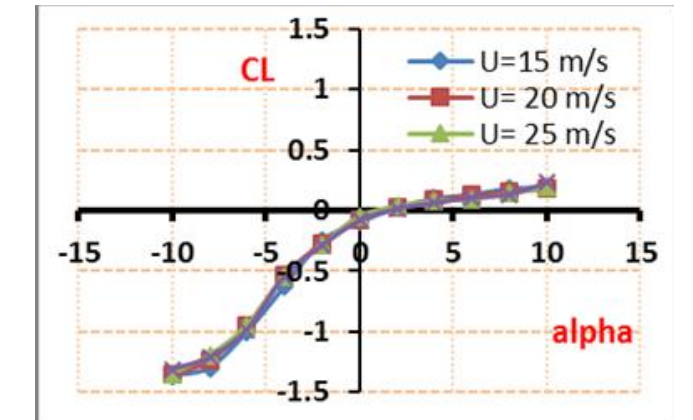

Gambar 23.

$\mathrm{C}_{\mathrm{L}}$ vs. alpha

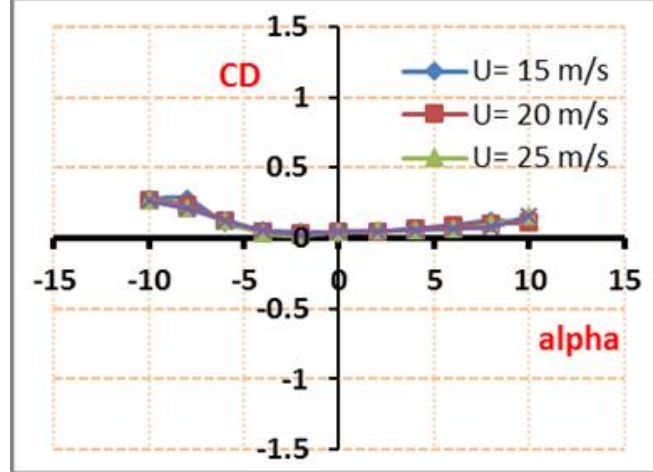

Gambar 24.

$\mathrm{C}_{\mathrm{D}}$ vs. alpha

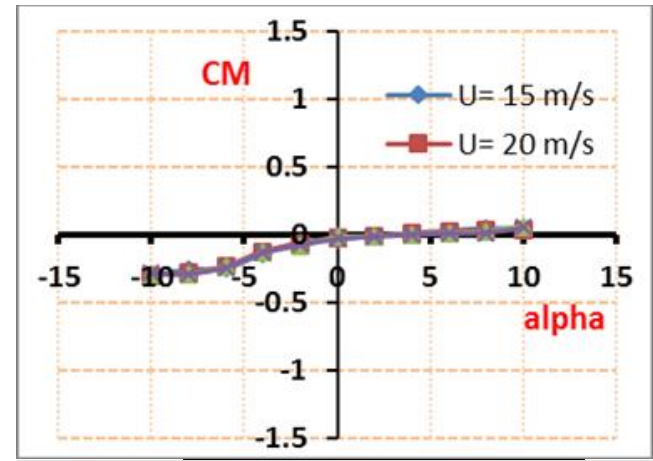

Gambar 25.

$\mathrm{C}_{\mathrm{M}}$ vs. alpha

Gambar 25 sampai Gambar 25 menunjukkan adanya variasi perubahan $C_{L}$, $C_{D}$ dan $C_{M}$ pada berbagai kecepatan angin atau bilangan Reynolds di terowongan angin $\left(\operatorname{Re}_{\mathrm{TA}}\right)$. Hubungan Bilangan Reynolds dan Kecepatan Angin ditunjukkan di Tabel 2.

Tabel 2.

Bilangan Reynolds Pengujian Statik

U

$\mathrm{Re}_{\mathrm{TA}}$

\begin{tabular}{ll}
\hline $15 \mathrm{~m} / \mathrm{s}$ & $5,41 \times 10^{5}$ \\
$20 \mathrm{~m} / \mathrm{s}$ & $7,21 \times 10^{5}$ \\
$25 \mathrm{~m} / \mathrm{s}$ & $9,01 \times 10^{5}$ \\
$30 \mathrm{~m} / \mathrm{s}$ & $1,08 \times 10^{6}$ \\
\hline
\end{tabular}

Kemudian dari hasil pengukuran $\mathrm{C}_{\mathrm{L}}, \mathrm{C}_{\mathrm{D}}$ dan $\mathrm{C}_{\mathrm{M}}$ dapat diturunkan pula laju perubahannya, terutama pada rentang $-2^{\circ}<$ $\square<+2^{\circ}$, seperti ditunjukkan di Tabel 3.

Tabel 3.

Perubahan Kurva CL, CD, CM

\begin{tabular}{cccc}
$\begin{array}{c}\text { Sudut } \\
\text { Datang } \\
\text { Angin }(\square)\end{array}$ & $\frac{d C L}{d \alpha}$ & $\frac{d C D}{d \alpha}$ & $\frac{d C M}{d \alpha}$ \\
\hline$-2^{\circ}<\square<+2^{\circ}$ & 0,068525 & 0,000136 & 0,011299 \\
\hline
\end{tabular}


Secara ringkas, dari hasil pengujian tersebut dapat diketahui bahwa:

- Efek Bilangan Reynolds sangat kecil, sehinga secara garis besar dapat dikatakan bahwa pada berbagai kecepatan angin nilai $C_{L}, C_{D}$ dan $C_{M}$ hampir sama

- Kurva $C_{L}$ dan $C_{M}$ adalah positif, dengan kata lain nilai $C_{L}$ dan $C_{M}$ naik dengan kenaikan sudut datang angin ( $\square$ ).

- $\quad$ Nilai $C_{D}$ adalah minimum pada $\square \square \square \square 2$

- Laju perubahan nilai $C_{\llcorner}$terhadap $\square, C_{D}$ terhadap $\square$ dan $\quad \mathrm{C}_{\mathrm{M}} \quad$ terhadap dirangkum pada Tabel 3.

- $\quad$ Dapat dilihat bahwa pada $\square \square=0^{\circ}$ dan kecepatan angin $\sim 30 \mathrm{~m} / \mathrm{s}$, gaya / momen aerodinamika tidak sama dengan nol, tetapi:

- Nilai $C_{L}=-0,08291$ berarti dek telah memiliki gaya angkat negatif

- Nilai $C_{D}=0,044568$ berarti dek telah memiliki gaya hambat positif

- Nilai $\mathrm{C}_{\mathrm{M}}=-0,03037$ berarti dek telah memiliki momen torsi negatif

\section{Uji Model Dinamik}

Model seksional dinamik adalah replika penggalan struktur dek jembatan bentang tengah (main-span) dan mensimulasikan osilasi yang dominan di bagian tersebut, yakni osilasi 2 DOF (Degree Of Freedom) :

- Gerak lentur vertikal (heaving), dengan variabel displacement $\left(\cdot_{h}\right)$

- Gerak torsional (torsion), dengan variabel displacement $\left(\cdot{ }_{\theta}\right)$

Ada dua kaidah kesetaraan yang harus dipenuhi oleh model seksional dinamik:

- Kaidah kesetaraan aerodinamika yang dinyatakan melalui kesetaraan bentuk geometry, dimana desain geometry ini merupakan geometry jembatan prototype.

- Kesetaraan dinamika struktur, yang secara praktis dapat dinyatakan oleh kesetaraan rasio frekuensi natural (eigen value) gerak torsi terhadap gerak heaving dari sistem struktur dek jembatan.

Untuk mereplika gerakan jembatan prototipe secara dinamik, maka model disangga oleh delapan sistem pegas yang konstanta pegasnya sama. Frekuensi osilasi heaving dikendalikan oleh rapat masa model dan frekuensi osilasi torsi dikendalikan oleh rapat momen inersia masa dan jarak antar pegas (2e).

Sistem suspensi pegas dipasang dalam seksi uji khusus yang dibatasi oleh dummy wall. Dalam dummy wall ini sistem pegas akan terlindung dari aliran angin. Sistem pegas terhubung ke model melalui mekanisme khusus yang memungkinkan dilakukannya penyesuaian / tuning / adjustment dari sistem pegas. Seperti penggantian pegas dengan stiffnes berbeda atau jarak antar pegas. Dengan mekanisme ini maka frekuensi natural dari model dapat disesuaikan sehingga memenuhi kaidah kesetaraan yang ditentukan.

Sketsa susunan sistem pegas dari model uji ditunjukkan di Gambar 26. Gambar 27 menunjukkan struktur sistem pegas sebenarnya untuk menyangga model di dummy wall.

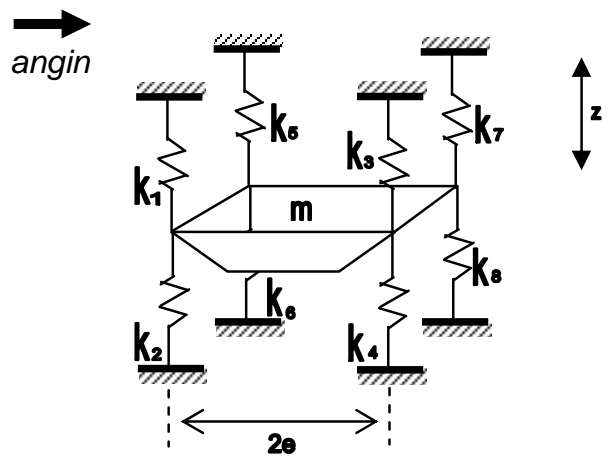

Gambar 26.

Sketsa Sistem Pegas Pada Model Seksional Jembatan

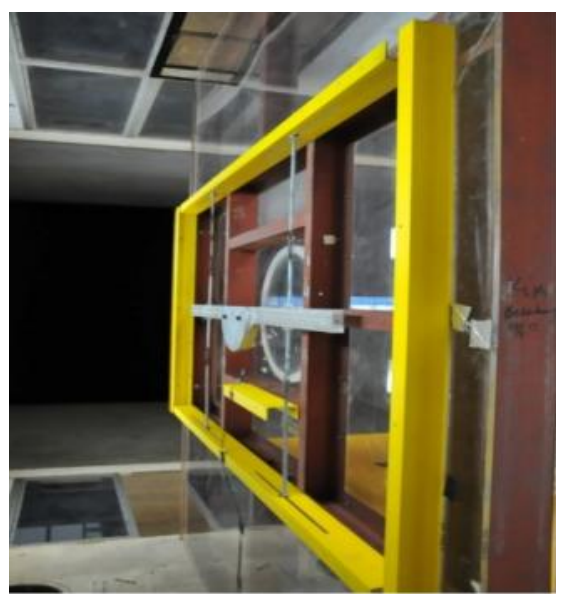

Gambar 27.

Sistem Pegas Model

Dengan sistem pegas tersebut maka rasio frekuensi natural model seksional dek dapat di atur (tune), sehingga memenuhi kaidah kesetaraan yang ditentukan. Pengaturan dilakukan dalam suatu proses yang disebut dengan Model Modal Measurement, hasilnya ditunjukkan di Gambar 28. 


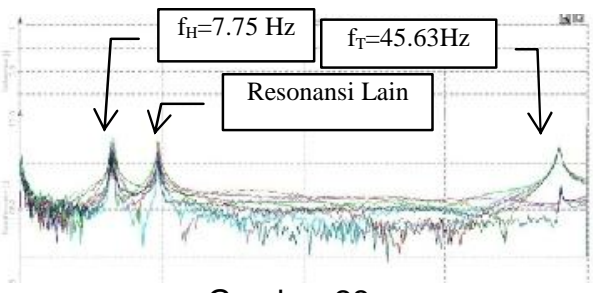

Gambar 28.

Hasil Modal Measurement dari model (puncak osilasi heaving di $_{H}$ danf $_{T}$ )

Tabel 4 menunjukkan rangkuman hasil pengaturan frekuensi natural model dibandingkan dengan frekuensi natural jembatan aktual (prototipe).

Tabel 4

Perbandingan Parameter Dinamika Struktur

\begin{tabular}{ccccc}
\hline No. & Uraian & $\begin{array}{c}\text { Proto- } \\
\text { type } \\
(\mathrm{Hz})\end{array}$ & $\begin{array}{c}\text { Model } \\
(\mathrm{Hz})\end{array}$ & $\begin{array}{c}\text { Model } \\
\text { LogDec } \\
(\delta)\end{array}$ \\
\hline 1. & $\mathrm{~F}_{\mathrm{H} 1}$ & 0.220 & 7,750 & $-0,0088$ \\
2. & $\mathrm{~F}_{\mathrm{T} 1}$ & 1.299 & 45,625 & $-0,0138$ \\
3. & $\mathrm{~F}_{\mathrm{T} 1} / \mathrm{F}_{\mathrm{H} 1}$ & 5.9 & 5,9 & \\
\hline
\end{tabular}

Setelah frekuensi natural model selesai di atur maka pengukuran response dinamik dari model ketika mendapat aliran angin, diukur menggunakan 2 buah accelerometer, yang ditempatkan masing-masing secara vertikal di sisi depan $\left(\mathrm{AC}_{1}\right)$ dan sisi belakang $\left(\mathrm{AC}_{2}\right)$. Gambar 29 menunjukkan sketsa penempatan accelerometer untuk mengukur respon model dek.

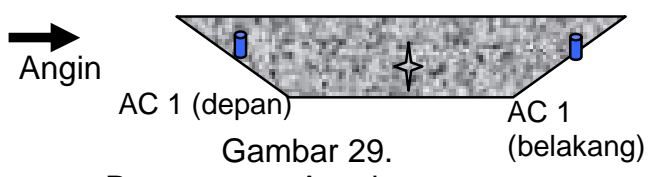

Penempatan Accelerometer
Model seksional dinamik diuji dengan 3 konfigurasi, masing-masing dengan sudut datang angin (sudut serang) yang berbeda: $\square \square=+3^{\circ}, 0^{\circ},-3^{\circ}$. Hal ini dipilih, karena pada umumnya defleksi torsional dek jembatan bentang panjang tidak akan lebih dari $\pm 3^{\circ}$. Jika keadaan aktual struktur jembatan yang akan dibangun adalah terrain flat maka sudut datang angin yang dominan adalah $\square \square=0$ deg.

Secara garis besar, objektif uji dinamik adalah untuk prediksi:

- Kecepatan kritis terjadinya eksitasi pada struktur dek oleh Induksi Resonansi (Resonance Induced Excitation): osilasi heaving $\left(U_{H}\right)$ dan torsi $\left(U_{T}\right)$

- Kecepatan kritis timbulnya flutter $\left(U_{f}\right)$

- Prediksi displacement (RMS) pada setiap kecepatan angin

Maka dari Tabel 4 diatas dapat dihitung persamaan kesetaraan berikut untuk mendapatkan hubungan transformasi kecepatan angin di terowongan angin dengan kecepatan angin aktual (prototype),

$$
\begin{aligned}
& \left.\left.\frac{1.298336(4.22)}{U_{p}}\right]_{p}=\frac{45.625(0.105)}{U_{T A}}\right]_{m} \\
& U_{p}=1.14 U_{T A}
\end{aligned}
$$

Hasil pengukuran induksi resonansi ditunjukkan di Gambar 30. Dapat dilihat bahwa pada dek jembatan tidak terjadi induksi akibat perbedaan tekanan permukaan atas/bawah dek yang disebut dengan LSHR (Low wind Speed Heaving Resonance), yang terlihat hanyalah induksi resonansi oleh vortex, VIV (Vortex Induced Vibration) atau Vortex Sheeding Induced. Sehingga ringkasan hasil pengukuran dapat ditulis seperti di Tabel 5 dan 6 .

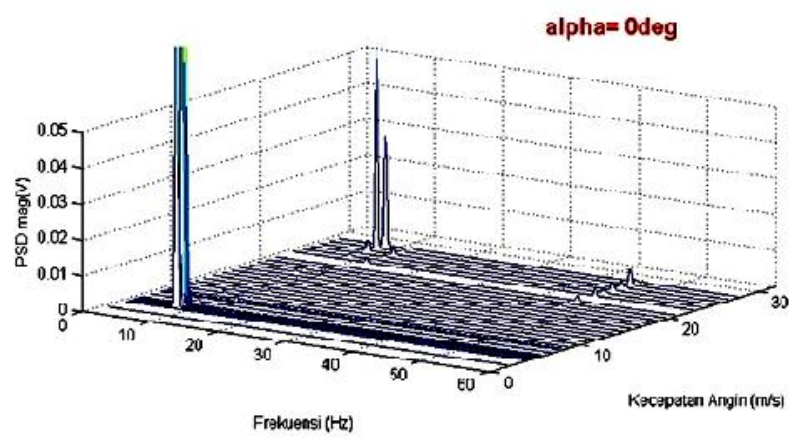

Gambar 30.

Hasil Pengukuran untuk Identifikasi RIV $\alpha=0^{\circ}$ 
Tabel 5 .

Hasil Identifikasi $\bigcup_{\mathbb{I R}}$ Pada Model

\begin{tabular}{ccc}
\hline Sudut & \multicolumn{2}{c}{ MODEL } \\
\cline { 2 - 3 } Datang & Heaving & Torsion \\
Angin $(\alpha)$ & $U_{I R-H}(\mathrm{~m} / \mathrm{dtk})$ & $U_{I R-T}(\mathrm{~m} / \mathrm{dtk})$ \\
\hline \multirow{2}{*}{$\alpha=0^{\circ}$} & 4.4 & 27 \\
& 5.2 & \\
$\alpha=+3^{\circ}$ & 6.0 & 29 \\
$\alpha=-3^{\circ}$ & 7.8 & \\
\hline
\end{tabular}

Tabel 6.

Prediksi $U_{\mathbb{R}}$ Pada Prototipe

\begin{tabular}{|c|c|c|c|c|}
\hline \multirow[b]{2}{*}{$\begin{array}{c}\text { Sudut } \\
\text { Datang } \\
\text { Angin }(\alpha)\end{array}$} & \multicolumn{4}{|c|}{ PREDIKSI PADA PROTOTIPE } \\
\hline & $\begin{array}{c}\text { Heav. } \\
U_{I R-H} \\
(\mathrm{~m} / \mathrm{dtk})\end{array}$ & $\begin{array}{c}\text { Max. } \\
\text { aksel. } \\
\text { (g) }\end{array}$ & $\begin{array}{c}\text { Torsion } \\
U_{I R-T} \\
(\mathrm{~m} / \mathrm{dtk})\end{array}$ & $\begin{array}{l}\text { Max. } \\
\text { aksel } \\
\text { (g) }\end{array}$ \\
\hline$\alpha=0^{\circ}$ & $\begin{array}{l}5,02 \\
5,90\end{array}$ & $\begin{array}{l}0,18 \\
0,31\end{array}$ & 30,8 & 0,06 \\
\hline$x=+3^{\circ}$ & 6,84 & 0,53 & & \\
\hline
\end{tabular}

\begin{tabular}{ccccc} 
& 8,90 & 0,35 & & \\
\hline & 6,38 & 0,004 & 40,6 & 0,03 \\
\hline
\end{tabular}

Untuk mendapatkan data kecepatan kritis flutter, maka sistem model dialiri angin dan diukur parameter Flutter Margin (Fm) sesuai Persamaan (11), dari kecepatan angin terendah sampai gejala flutter terlihat. Namun secara matematis hubungan kurva antara Fm dengan kecepatan angin adalah parabolic, sehingga untuk tujuan praktis agar kurva Fm linier maka yang dibuat adalah kurva Fm terhadap q (tekanan dinamik) dengan satuan Pascal. Gambar 31 menunjukkan kurva Fm terhadap q $[\mathrm{Pa}]$ dari hasil pengukuran pada $=+3^{\circ}$. Maka ekstrapolasi kurva tersebut ke $\mathrm{Fm} \rightarrow 0$ memberikan data tekanan dinamik $\mathrm{q}$ $[\mathrm{Pa}]$ atau kecepatan angin flutter $\mathrm{U}_{\mathrm{f}}[\mathrm{m} / \mathrm{s}]$.

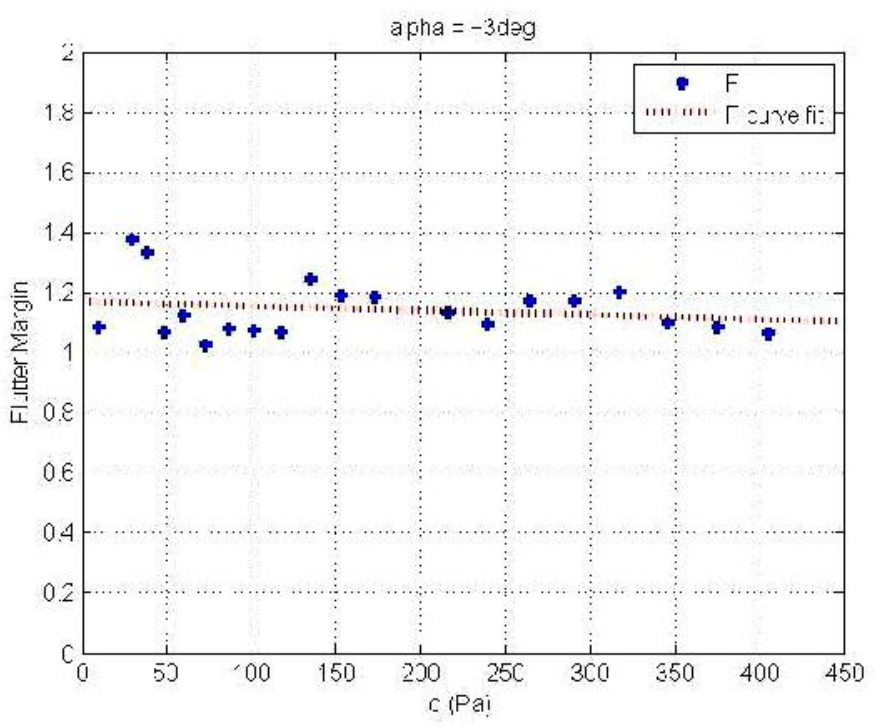

Gambar 31.

Kurva $F \mathrm{~m}$ pada alp $=+3^{\circ}$ (terowongan angin: $q_{c}=8054, U_{f T A}=115 \mathrm{~m} / \mathrm{s}$ ) atau (prototipe: $U_{f}=131 \mathrm{~m} / \mathrm{s}$ )

Tabel 7.

Hasil Stability Test (Flutter Margin Test)

\begin{tabular}{cccc}
\hline $\begin{array}{c}\text { Sudut } \\
\text { Datang } \\
\text { Angin }\end{array}$ & $\begin{array}{c}\text { Tekanan } \\
\text { Dinamik } \\
\text { Angin } \\
\mathbf{( P a )}\end{array}$ & $\begin{array}{c}\text { Kecepatan } \\
\text { Kritis } \\
\text { Flutter di } \\
\text { Ter. Angin } \\
\mathbf{U}_{\mathrm{f}-\mathrm{TA}}(\mathbf{m} / \mathbf{s})\end{array}$ & $\begin{array}{c}\text { Kecepatan } \\
\text { Kritis } \\
\text { Flutter di }\end{array}$ \\
$\begin{array}{cccc}\mathbf{U}_{\mathbf{f}} \text { (m/dtk) } \\
\text { (motype }\end{array}$ \\
\hline$\alpha=0^{\circ}$ & 4397 & 85 & 96,9 \\
$\alpha=+3^{\circ}$ & 8054 & 115 & 131 \\
$\alpha=-3^{\circ}$ & 7870 & 114 & 130 \\
\hline
\end{tabular}

Hasil pengukuran kecepatan angin terjadinya flutter pada tiga sudut datang angin (alpha) dirangkum di Tabel 7. Karena pengujian telah dilakukan pada tiga sudut datang angin, maka diperoleh tiga kecepatan kritis flutter.

Kecepatan kritis flutter untuk rujukan dapat digunakan kaidah worst condition, yakni dengan mengambil kecepatan angin kritis yang terendah, dalam hal ini adalah 85 $\mathrm{m} / \mathrm{s}$ di terowongan angin atau $96,9 \mathrm{~m} / \mathrm{s}$ di lingkungan aktual (prototype).

Displacement (defleksi / perpindahan) dek dari model dapat di-estimasi dari pengukuran akselerasi a model seksional melalui hubungan ${ }^{5}$,

$$
\delta=\left|\frac{a}{\omega^{2}}\right|
$$

dimana, 
$\omega$ adalah frekuensi-putar yang dijadikan rujukan

Karena displacement dek adalah data yang berfluktuasi setiap saat (dalam domain waktu), maka estimasi displacement ini lebih tepat untuk dinyatakan dalam besaran RMS (Root Mean Square) dari variabel $\square$. Gambar 32 dan 33 menunjukkan hasil pengukuran displacement deck untuk masing-masing gerak heaving dan torsi.

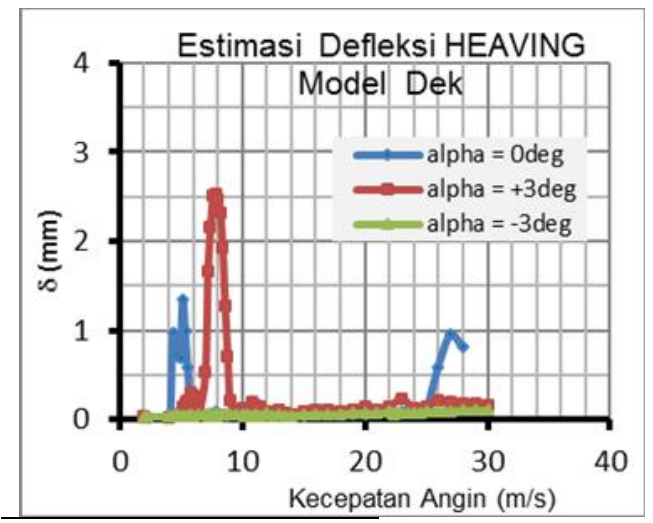

Gambar 32.

RMS Heaving Deflection

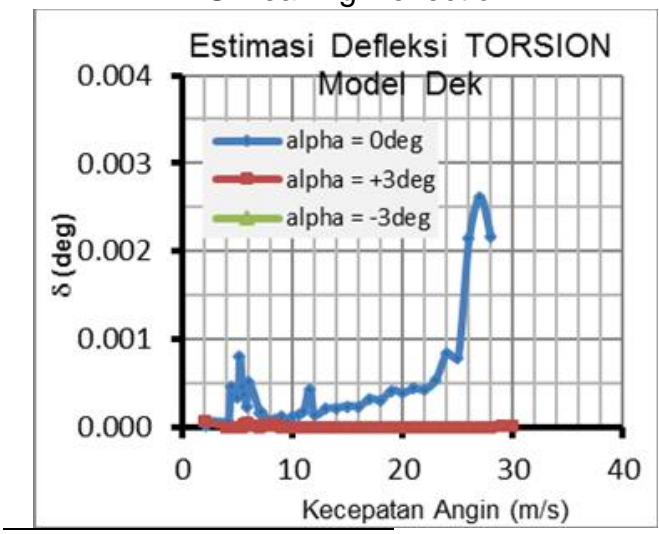

Gambar 33.

RMS Torsion Deflection

Tabel 8.

Defleksi Dek ( $\delta$ ) Saat Terjadi Induksi Resonansi di Model

\begin{tabular}{ccccc} 
& \multicolumn{4}{c}{ Resonansi di Model } \\
\hline Sudut & \multicolumn{4}{c}{ Torsion } \\
Datang & \multicolumn{2}{c}{ Heaving } & $U_{I R-T}$ & $\delta_{T}$ \\
Angin & $U_{I R-H}$ & $\delta_{H}$ & $U_{I R-1}$ & $($ deg $)$ \\
\hline$(\alpha)$ & $(\mathrm{m} / \mathrm{s})$ & $(\mathrm{mm})$ & $(\mathrm{m} / \mathrm{s})$ & 0,948 \\
$\alpha=0^{\circ}$ & 4,4 & 0,967 & 27 & 0,170 \\
& 5,2 & 0,984 & & \\
$\alpha=+3^{\circ}$ & 6,0 & 0,272 & 29 & 0,170 \\
$\alpha=-3^{\circ}$ & 7,8 & 2,525 & & \\
\hline \multirow{2}{*}{$\alpha, 8$} & 0,519 & 29 & 0,103 \\
\hline
\end{tabular}

Secara numerik, rangkuman hasilnya ditunjukkan di Tabel 8 dan 9. Tampak bahwa disekitar frekuensi heaving terjadi dua puncak defleksi untuk sudut datang angin $\alpha=0^{\circ}$ dan $3^{\circ}$, sedangkan untuk $\alpha=-3^{\circ}$ hanya terjadi satu puncak defleksi.

Tabel 9.

Prediksi Defleksi Dek $(\delta)$ Saat Terjadi Induksi Resonansi di Prototipe

\begin{tabular}{|c|c|c|c|c|}
\hline \multirow{3}{*}{$\begin{array}{c}\text { Sudut } \\
\text { Datang } \\
\text { Angin } \\
(\alpha)\end{array}$} & \multicolumn{4}{|c|}{ PROTOTIPE } \\
\hline & \multicolumn{2}{|c|}{ Heaving } & \multicolumn{2}{|c|}{ Torsion } \\
\hline & $\begin{array}{l}\mathbf{U}_{\mathrm{IR}-\mathrm{H}} \\
(\mathrm{m} / \mathrm{s})\end{array}$ & $\begin{array}{c}\delta_{H} \\
(\mathrm{~mm})\end{array}$ & $\begin{array}{l}\mathbf{U}_{\text {IR-T }} \\
(\mathrm{m} / \mathrm{s})\end{array}$ & $\begin{array}{c}\delta_{\mathbf{T}} \\
\text { (deg) }\end{array}$ \\
\hline$\alpha=0^{\circ}$ & $\begin{array}{l}5,0 \\
5,9\end{array}$ & $\begin{array}{l}38,689 \\
39,375\end{array}$ & 30,8 & 0,948 \\
\hline$\alpha=+3^{\circ}$ & $\begin{array}{l}6,8 \\
8,9\end{array}$ & $\begin{array}{r}10,866 \\
100,993\end{array}$ & 40,6 & 0,170 \\
\hline$\alpha=-3^{\circ}$ & 6,4 & 20,775 & 40,6 & 0,103 \\
\hline
\end{tabular}

Pada Tabel 8 dan 9 ditemukan pula beberapa kemungkinan adanya $L C O$ yang tidak memenuhi tingkat kenyamanan menurut British Rules maupun ASCE, terutama pada saat terjadi resonansi heaving dan arah datang angin $\alpha=0^{\circ}$.

Namun perlu dicatat bahwa osilasi ini sangat dipengaruhi oleh lingkungan angin sekitar jembatan, seperti besar kecepatan $(\mathrm{U})$, arah angin $(\theta)$ dan tingkat turbulensi angin datang $\left(\mathrm{I}_{\mathrm{v}}\right)$. Proses fatigue dapat terjadi apabila struktur jembatan sering mengalami osilasi resonansi, misalnya jika angin yang melalui secara rata-rata sering berada sekitar kecepatan kritis.

\section{SIMPULAN}

Dari uraian diatas serta studi kasus pengujian yang telah diuraikan, maka dapat diketahui bahwa uji seksional model dek jembatan sudah cukup memadai sebagai perangkat dasar atau proses awal dalam analisis aeroelastik jembatan bentang panjang. Karena dari uji ini telah diperoleh beberapa hal berikut:

- Gaya aerodinamika steady yang sangat erat kaitannya dengan bentuk geometri penampang (cross-section, 2D) dari dek jembatan bagian tengah (main-span).

- Fenomena aeroelastik induksi vortex dan flutter. Masing-masing fenomena menyebabkan dek jembatan terdeformasi.

- Deformasi akibat induksi vortex tidak bersifat katastropik, hanya menimbulkan gangguan pada struktur dalam beberapa saat. Jika hal ini sering terjadi dalam jangka waktu lama, bisa saja timbul kelelahan struktur (fatigue). 
- Deformasi akibat flutter bersifat katastropik, apabila terjadi maka secara keseluruhan struktur dek akan hancur.

- Uji terowongan angin sudah dapat memperkirakan besarnya deformasi dek pada setiap kecepatan angin. Namun perkiraan ini harus dikoreksi jika ada perbedaan koeffisien redaman struktur model dan prototype.

- Jika deformasi dek cukup kecil, dalam arti berada dalam tingkat kenyamanan yang dibolehkan, maka rancangan jembatan dianggap layak untuk dibangun.

Secara ringkas dapat dikatakan bahwa uji model seksional dek hanya mereplika geometri serta gerakan dek pada penggalan bentang tengah dek, sehingga struktur model menjadi lebih sederhana, pembuatannya menjadi jauh lebih murah dan cepat, begitupula replika detail geometri dapat dibuat dengan ukuran lebih besar. Dengan demikian uji model seksional akan lebih akurat dalam mendeteksi timbulnya induksi resonansi, dimana profil geometri akan lebih besar dan mendekati bentuk aslinya.

Namun untuk menentukan kecepatan kritis flutter, metoda uji model seksional kurang akurat dibanding model penuh. Pada uji model seksional kecepatan kritis flutter diperoleh dari hasil ekstrapolasi, pendekatan model matematika atau metoda grafik. Pada uji model penuh, pengujian dilakukan sampai terjadi flutter, sehingga prediksi kecepatan kritis flutter akan langsung diperoleh pada saat pengujian.

Kemudian, jika ternyata hasil uji terowongan angin yang mendeteksi adanya fenomena yang mungkin membahayakan struktur atau kurang sesuai dengan spesifikasi yang dirancang semula, maka perencana jembatan dapat merubah rancangannya dengan menggeser frekuensi natural menjadi lebih tinggi atau rendah, sehingga resonansi tidak terjadi di kecepatan angin rata-rata atau dengan merubah bentuk geometrinya agar kecepatan flutter terjadi di kecepatan angin cukup tinggi, jauh di atas kecepatan angin rata-rata.

\section{UCAPAN TERIMA KASIH}

Terima kasih penulis sampaikan kepada tim pengujian jembatan. Untuk almarhum Drs. Sariman, MSc yang telah membantu tersedianya data untuk analisis. Juga pada anggota troika pengujian yang bersama penulis melakukan pengujian, Ir. Wibawa Purabaya MT., Drs. Dadang Kuswandi dan Matza Gusto Andika, ST., MT.

\section{DAFTAR PUSTAKA}

1. Sachs, P., Wind Forces in Engineering, Pergamon Press, Oxford, 1978

2. Anderson, J. D., Fundamentals Aerodynamics, Mc Graw-Hill Book Company, New York, 1985

3. Simiu, E. and Scanlan, R.H., Wind Effects on Structures 3rd Edition, John Wiley and Sons Inc, New York, 1996

4. Holmes, J.D., Wind Loading of Structures, Spon Press, London, 2001

5. Rao, S.S., Mechanical Vibrations, 3rd. ed. , Addison-Wesley Publishing Company, Singapore, 1995

6. Irwin, P.A., Full aeroelastic model test, Proceedings: Aerodynamics of Large Bridges, Balkema, Coppenhagen, 1992

7. Persoon, A. J., The use of sectional and full aeroelastic models, Personal Communication, 2004

8. Tanaka, H., Similitude and Modelling in Bridge Aerodynamics, Proceedings : Aerodynamics of Large Bridges, Balkema, Coppenhagen, 1992

9. Scanlan, RH., Theory of the wind analysis of long span bridges based on data obtainable from sectional model test, Proceedings of the International Conference on Wind Effects on Building and Structures, Cambridges University Press, 1977

10. Tubino, F., Relationships among aerodynamic admittance functions, flutter derivatives and static coefficients for longspan bridges, Journal of Wind Engineering and Industrial Aerodynamics 93 (2005) 929-950, Elsevier, 2005

11. Fariduzzaman, L. Gunawan, L. R. Zuhal dan A. Nasution, Uji Aeroelastik Model Penuh pada Jembatan Cable Stayed, Jurnal Teknik Sipil, Vol 11 no. 2 April 2004, Departemen Teknik Sipil ITB, Bandung, 2004

12. Bartoli, G., Righi, M., Flutter Mechanism for rectangular prisms in smooth and turbulent flow, Journal of Wind Engineering and Industrial Aerodynamics 94 (2006) 275-291, Elsevier, 2006

13. Benneth, R.M, Application of Zimmerman Flutter Margin Criterion to A Wind Tunnel Model. NASA TM 84545

14. Boonyapinyo, V., Lauhatanon, Y., Lukkunaprasit, P., Nonlinear aerostatic stability analysis of suspension bridges, Journal of Engineering Structures 28 (2006) 793-803, Elsevier, 2006 
15. Lia, Y., Qiang, S., Liao, H., Y.L. Xu,Y. L., Dynamics of wind-rail vehicle-bridge systems, Journal of Wind Engineering and Industrial Aerodynamics 93 (2005) 483-507, Elsevier, 2005

16. Bartoli, G., Righi, M., Flutter mechanism for rectangular prisms in smooth and turbulent flow, Journal of Wind Engineering and Industrial Aerodynamics 94 (2006) 275-291, Elsevier, 2006

17. Zhu, L. D., Wang, M., Wang, D. L., Guo, Z. S., Cao, F. C., Flutter and buffeting performances of Third Nanjing Bridge over Yangtze River under yaw wind via aeroelastic model test, Journal of Wind Engineering and Industrial Aerodynamics 95 (2007) 1579-1606, Elsevier, 2007

18. Ge, Y. J. and Xiang, H. F., Recent development of bridge aerodynamics in China, Journal of Wind Engineering and
Industrial Aerodynamics 96 (2008) 736768, Elsevier, 2008

19. Chen, Z, Han, Y., Luo, L.Z., Hua, X., Identification of aerodynamic parameters for eccentric bridge section model, Journal of Wind Engineering and Industrial Aerodynamics 98 (2010) 202214, Elsevier, 2010

20. Torrielli, A., Tubino, F. and Solari, G., Effective wind actions on ideal and real structures, Journal of Wind Engineering and Industrial Aerodynamics 98 (2010) 417-428, Elsevier, 2010

21. Ubertini, F., Hong, A. L., Betti, R. and Materazzi, A. L., Estimating aeroelastic effects from full bridge responses by operational modal analysis, Journal of Wind Engineering and Industrial Aerodynamics 99 (2011) 786-797, Elsevier, 2011 